Towards A Consistent System of Sustainable Management Accounting for Enhancing Decisions Making: An Experimental Study

Mohamed Abdelmounem Serag Assistant Professor in Accounting Department

Sadat Academy for Management Sciences

Address: Kingdom of Saudi Arabia, King Khalid University, College of Administration and Financial Sciences, ABHA, P.O. Box: 3247, Postal Code: 61471

Tel.+966593767651

Email: mohserag1970@yahoo.com 


\section{نحو نظام متتاسق للمحاسبة الادارية الموجه نحو الاستدامة لتدعيم أتخاذ القرارات: دراسة تجريبية}

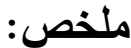

على الرغم من الدور المعنوي لنظم المحاسبة الإدارية الموجه نحو الاستدامة في تدعيم أتخاذ القرارات المتعلقة بأبعاد الاستخامة في الوقت الحالي، إلا أن هناك نقص في الدراسات التجريبية عن تأثثر نظم المحاسبة الإدارية الموجه نحو الاستدامة على ادماج

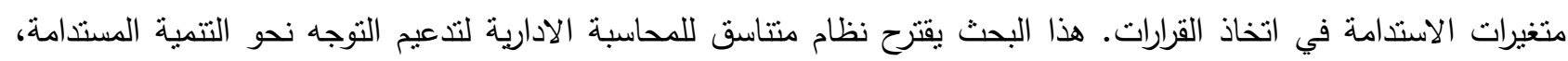
ويمثل أطار للمتغيرات التي يتم اختبارها من خلال الدراسة التجريبية. وتمنلت فروض الدراسة التجريبية في أن نوفير المعلومات

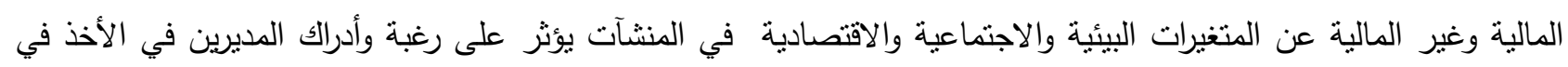

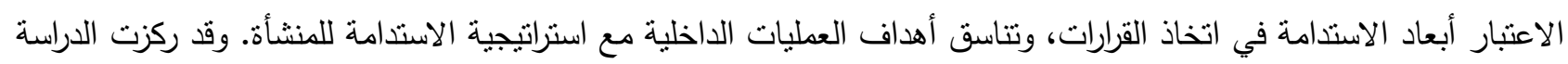
التجريبية على اختبار الفروض في إطار بديلين للنظام المحاسبي ، النظام المحاسبي المالي والتكاليفى التقليدي والنظام الدحاسبي التبني الإداري المقترح الموجه نحو الاستدامة. وقد تم تجميع بيانات الدراسة من خلال استقصاء لاستجابات عينة من المديرين فى لئ

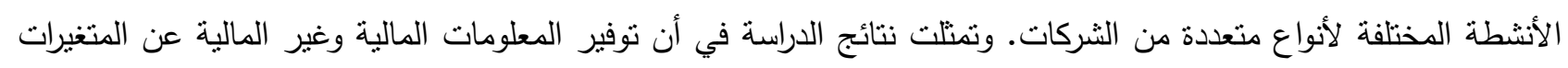
البيئية والاجتماعية في ظل نظام منتاسق للححاسبة الإدارية موجه نحو الاستدامة يؤثز على زيادة وعى وأدرالك الميرين بأهمية إدماج منل هذه المتغيرات في أتخاذ القرارات وذلك بالمقارنة بالنظام المحاسبي المالي والتكاليفى التقليدي. وتمنل نتائج الدراسة التجريبية الدافع للمؤسات المهنية على أهمية تطوير معايير الإفصاح والتقرير للأخذ فى الاعتبار كيفية الإفصاح عن الأبعاد البيئية والاجتماعية للشركات. ايضاً يمنل البحث مساهمة فى كيفية بناء نظام متتاسق للمحاسبة الإدارية موجه نحو تدعيم قرارات الإنية الاستخامة في المنشآت.

المصطلحات الرئيسية : نظام متتاسق للمحاسبة الإدارية موجه نحو الاستدامة، أدوات المحاسبة الإدارية المرتبطة بالاستدامة، أتخاذ القرارات المتعلقة بالاستدامة، المعلومات المالية وغير المالية لأبعاد الاستدامة. 


\title{
Towards A Consistent System of Sustainable Management Accounting for Enhancing Decisions Making: An Experimental Study
}

\begin{abstract}
Given the important role that properly designed sustainable management accounting (SMA) may play in helping firms to face their social and environmental responsibilities better, there is little evidence about how management accounting system to support sustainable decisions-making within companies. We suggested a consistent system of SMA, which could be used to study the research topic empirically. An experimental study was carried out focusing on the basic idea that whether the availability of sustainable cost information affects the willingness of managers to take sustainable considerations into account in their sustainable decisions and to align their processes with sustainability goals in the context of two alternatives of company s' accounting systems. Data collected by taking responses from a variety of managers in a sample of large companies operating in Egypt. The evidence reported here reveals that when sustainability cost information is available to managers at various stages of the supply chain, they are more willing to take sustainable decisions and align their processes with sustainability goals in the case of using the alternative of SAMS. We leverage these findings into a series of research questions to stimulate the interests of accounting academics for future accounting or interdisciplinary research in sustainability. These results have several implications for public policy in Egypt and accounting practice. Also, it allows researchers to develop a better theory of how to build decision-focused sustainability management accounting system to improve competitiveness and create long-term firm value.
\end{abstract}

Keywords: sustainable management accounting system (SMAS); sustainable decisions making; sustainability-related management accounting tools; sustainable cost information; experimental study. 


\section{Introduction}

The last decades have witnessed a growing consensus and increasing regulation underpinning the notion that firms have environmental and social responsibilities and that 'good' business practices can provide a contribution towards the achievement of sustainable development goals ${ }^{1}$ (United Nations Conference on Trade and Development 1996; World Business Council for Sustainable Development 2001; AccountAbility $^{2}$ 2008). Confronted with ever-escalating pressures from multiple sources (governments, NGOs, social rating agencies, public opinion and so on) to operate in a socially and environmentally responsible fashion. Businesses have started to embrace the sustainability rhetoric in their external reporting and disclosures (Gond et al. 2012), claiming that engaging in sustainability is an important activity (Spence 2007).

The movement towards integrating these issues into internal and external reports is evidenced by the publication of more comprehensive corporate sustainability reports supported by guidelines such as those of the Global Reporting initiative (2011) labeled as the "triple bottom line.",

Academic research on the topic has also flourished. This literature, variously named as social accounting, sustainability accounting or social and environmental accountability (Deegan 2002; Gray 2002), has so far extensively explored issues relating to external social and environmental reporting and in particular to its determinants (see, e.g. Adams, 2002; Adams and Whelan 2009; Gray 2010; Gray et al. 1995; Owen 2008); Spence (2007). However, the management accounting literature has only sparsely adopted sustainability issues (Thomson 2007).

Sustainability management accounting is full of models that may emanate from conceptualizations that are sometimes widely opposed, as the "outside-in" and "inside-out" models (Burritt and Schaltegger 2010). The former is often associated with sustainable communication, while the latter involves the integration of the sustainability issues into the managers' decision-making processes (Cho and Caron 2013). What is problematic beyond this distinction is that much less attention has been devoted to the intra-organizational impact of sustainability and in particular to the role of management accounting systems supporting sustainability within

\footnotetext{
${ }^{1}$ The term corporate sustainable development is used to mean the processes which are implemented in order to reduce negative impacts and to increase the positive effects of corporations towards attaining a sustainable economy, environment, and society, whilst corporate sustainability represents the desired outcome of such processes (Schaltegger and Wagner 2006). In corporate practice, the focus is usually on the processes rather than on the end state, representing in essence an incremental process of continual development towards sustainability.

${ }^{2}$ SustainAbility is a consultation company established in 1987, which advises clients on the risks and opportunities associated with corporate responsibility and sustainable development. See its homepage at http://www.sustainability.com.

${ }^{3}$ A contemporary development is the G3.1 which is an update and completion of the third generation of GRI's Sustainability Reporting Guidelines Triple bottom line reporting contains three types of performance: financial (or economic), social and environmental; it is a comprehensive reporting process focused on a broader range of stakeholders, including various environmental and social interest groups.
} 
organizations (Bebbington 2007; Bonacchi and Rinaldi 2007; Durden 2008; Songini and Pistoni 2012).

This gap is particularly unfortunate given the important role that properly designed sustainable management accounting systems (SMAS) may play in helping firms embracing sustainability as a strategic goal to face their social and environmental responsibilities better, pushing them in the direction of sustainability Gond et al. (2012); (Henri and Journeault 2010); Songini and Pistoni (2012). Indeed, providing social and environmental performance measures to external stakeholders through sustainability reports is ineffective if these data are not also used for internal decision-making and control purposes Adams (2002); (Perego and Hartmann 2009). (Porter and Kramer 2006) Assert that sustainability management accounting tools create long-term value to the extent that they are integrated with organizational strategy. The strategic integration of sustainable management accounting tools embeds sustainability into organizational decision-making, promotes better resource allocation, and forms the basis for integrating sustainability reporting with traditional financial reporting (Ballou 2012).

Literature has long recognized that such reports may represent impression management techniques or 'green washing' phenomena aimed at maximizing perceptions of legitimacy but with little, if any, effects on the real work of organizations (Larrinaga-Gonzalez and Bebbington 2001; Neu et al. 1998; Laufer 2003). On the other hand, a few studies on the interplay among external sustainability reporting and sustainability decision-making mechanisms have also started to shed light on the instances in which external reporting initiatives may spur management accounting change towards more sustainable business operations (see, e.g., Adams and McNicholas 2007; Bouten and Hooze' 2013).

According to the development process proposed by Joshi and Krishnan 2010, the evolution of conventional sustainability accounting systems shifts from sustainability reporting systems to the sustainable management accounting system (SMAS) across three stages. The emphasis shifts from mainly periodic external reporting requirements to recognizing the need to collect more disaggregated sustainability information to the third stage facilitating continual effective internal decision-making incorporating sustainability considerations. Unfortunately, very few firms reach this final stage of evolution toward a SMAS. Instead, most sustainability accounting systems remain at the first or second stage and therefore do not provide comprehensive decision-relevant information to meet the goals of becoming an environmentally sustainable and socially responsive organization (Joshi and Krishnan 2010).

However, the fact that "traditional accounting systems" and "ecological accounting system" continue to be separate accounting and management systems to the companies working in Europe (Bartolomeo et al. 2000), should not be an obstacle to 
the "integration" of their separate findings and results. The "integration" of traditional accounting (divided into three main sub-systems: cost and management accounting, financial accounting and other traditional accounting) with ecological accounting (divided into three main sub-systems: internal ecological accounting, external ecological accounting and other sustainability accounting) would facilitate both the calculation of eco-efficiency and the process of decision-making by management and stakeholders (Schaltegger 1998). The integration of various systems is seen by prominent researchers as the final stage in the evolution of a system to assist strategic thinking within the firm (Adams and Frost 2008). On the other hand, environmental accounting is part of a massive and complex system called sustainability accounting. Sustainable development is more inclusive than ecoefficiency and captures a wide range of objectives that go unnoticed by ecoefficiency considerations, for instance, environmental concerns that are hard to quantify such as biodiversity or social aspects many of which are qualitative (Figge and Hahan 2013).

The reasons for using SMAS in the manager's decision-making are based on the idea that SMAS can be useful for performing two roles within decision-making ${ }^{4}$; decision-influencing information and decision-facilitating information.

Responding to calls for more research which engages with sustainable management accounting (SMA) for enhancing decision making, this study sheds light on the extent to which SMA are integrated into the planning, performance management, and risk management operations of organizations. Specifically, it considers: (1) How to build decision-focused sustainable management accounting system that facilitated the integration of sustainability considerations into management decision-making? and (2) Does the use of the consistent system of SMAS compared with the use of conventional financial, cost accounting system influence on the motives of managers in firms to integrate sustainability considerations into decision making and to align their processes with sustainability goals?

The paper divided into four main sections, the first part after introduction gives an overview of the literature of the sustainable management accounting research. The second part includes research gap, proposed a consistent system of SMA, hypothesis development. The third part includes an experimental study. Finally, conclusions are drawn and some suggestions for future research outlined.

\footnotetext{
4 According to (Demski and Feltham 1976) accounting information can perform two roles within decision-making. Decisionfacilitating information is intended to reduce the pre-decision uncertainty of the decision-maker and, thereby, enhance the probability to make better decisions with respect to the desired objectives. While the decision-facilitating role of information is relevant even for individual decisions, the decision-influencing function is important only in multi-person contexts. Decision-influencing information is intended to affect the behavior of (other) persons and in the management context, particularly, to influence managerial decisionmaking. Decision-influencing information enfolds its effects via monitoring of behavior, measurement and evaluation of performance and rewarding or penalizing performance (Wall and Greilling 2011).
} 


\section{Literature review}

Two approaches suggested in the literature can consider for our study and the problem of decision-making in the company. The first comes from a financial accounting approach and the need to ensure a positive and broader impact of company activities on society and the environment. Social and environment accounting (SEA) literature have been largely responsible for prompting many companies to produce corporate social responsibility reporting in the last few decades.

However, there is a second approach in the literature, usually defined as a "Managerialist approach" or "management accounting approach," that provides information analysis on how to support internal decision-making (Environmental management accounting literature). In practice, these two approaches often overlap each other, and the question of a "managerialist approach" exists and requires more definition (Marelli 2013).

\section{Social and environmental accounting approach}

The social and ecological accounting approach is very critical and has been growing in the accounting research literature over the past forty years, moving from the margins of accounting literature to Centre stage in recent years (Parker 2011). The critical time of transformation was at the end of the 1980s. In that period the SEA research considered the emergence of environmental accounting and auditing issues as an important perspective, and it is characterized by significant key research developments Owen (2008).

A predominantly managerialist approach is discernible in much of this research, witnessed by the almost complete displacement of the social dimension, along with an apparent desire to promote accounting and reporting systems in ways where the environmental dimensions may be conveniently captured in the interests of promoting economic efficiency. A more critical problem can also become important, i.e., the internalization of external environmental costs, via full- cost accounting methods, in the evolution of life cycle costing tools, and in the introduction of the social aspects as eco-justice issues (Marelli 2013).

Since businesses started discovering "sustainability" as a matter of critical concern, as part of a broader issue of competitiveness, companies have been attracted by innovation and opportunities for product and process changes. This phenomenon is evidenced in part by the growth in popularity of "triple bottom line" reporting, or "sustainability" reporting Global Reporting Initiative (2011), encompassing the social and economic as well as the purely environmental dimension. SEA investigates the use management accounting within organizations where environmental accounting can be mobilized as a means of encouraging them to change and reduce company unsustainability. This perspective, called "organizational change," debates the efficacy and the need for EMA. In the 
beginning, EMA was considered only an environmental management tools designed to trace and track environmental costs and physical environmental flows (Bennett and James 1998), but the debate on developments in sustainability accounting and reporting shows the necessity to integrate external with internal reporting.

\section{Managerialist approach}

The managerialist approach was presented in the 1970s but found a more defined pathway of analysis with the creation of a pattern based on EMA. In fact, EMA was defined, after an interesting debate only at the end of the 1990s, as a set of tools that includes internal monetary and internal physical accounting to stress the necessity of integration of ecological and monetary issues (Burritt et al. 2002). The proposed framework can encourage the process of integration of two major components of environmental management accounting Burritt et al. (2002):

MEMA: monetary environmental management accounting.

PEMA: physical environmental management accounting.

Within this framework the possibility for managers to apply different tools for past/future and short- or long-term time managerial decisions is described.

EMA related to process costing (and can, therefore, be considered as environmental cost accounting) as well as focusing on environmental performance and management systems and physical and economic information. It measures the flow of energy, water, products, and materials used. If well designed and implemented, EMA helps to ensure better internal management and decision-making for investment appraisal, cleaner production, improving eco-efficiency and calculating within organizations. In the green company, the role of EMA is also relevant to developing the relationships with its stakeholder groups, in particular, public institutions and non-government organizations $\left(\mathrm{NGO}_{\mathrm{s}}\right)$. The date produced through the EMA serves as a basis for external accounting and reporting (Jasch 2006). EMA became interesting for internal decision-making processes because it affects management control systems (MCS) and performance measurement.

In addition to those concerns, eco-efficiency concepts have emerged. The relationship between EMA and economic performance has been developed, based on socio-economic theory (Birkin and Woodward 1997a, 1997b). However, within this pathway, the information requirements and the scope of implementation depending on the type of efficiency that is being considered. Correct information derived from management accounting is a prerequisite for determining eco-efficiency. Ecoefficiency claims that it is possible to increase productivity and thus reduce costs while simultaneously improving environmental performance (Bebbington 2001; Lehman 2002; Stone 1995). The eco-efficiency paradigm has implications for environmental management accounting and environmental cost management. It is consistent with the "win-win" green paradigm that innovative solutions can promote improvement in competitiveness and in environmental concerns. The practice 
highlights the difficulties in using the eco-efficiency ratio.

The sustainability accounting movement has quite suddenly produced innovation and push for different implementation in budget activities, capital investment decisions, life-cycle costing, supply chain management and key performance indicators systems to achieve more profitable solutions. According to the efficient-choice perspective in the diffusion of innovation (Abrahamson 1991), the main force driving the adoption of new management techniques is explicitly and implicitly the need for solving the challenges and complex managerial tasks. Consequently, SMAS can be considered for adoption to help companies achieve their goals, to avoid environmental and social risks, and to improve poor economic performance.

\section{Research gap, conceptual framework, and hypothesis development}

\section{3-1. Research gap}

It is increasingly the case that, to survive and thrive, companies must make decisions, which serve the interests of the environment and social. A growing number of organizations have been forced to respond to concerns about their social and ecological impacts including, for example, James Hardie, Nestle, Nike, and Shell Adams and Frost (2008).

Adams and Frost (2008) indicated that data collected by organizations on their social and environmental impacts does not ensure that managers will make decisions which appropriately balance social, environmental or economic impacts or properly prioritize the various stakeholder claims, but it can provide the basis for more informed decision-making. Business case proponents of an approach where decisionmaking is informed by social and environmental impact data would expect to use a convergence between corporate and social interests. There are examples of companies leading the way in influencing society to be more environmentally friendly. For example, energy and water companies provide customers with data on resource use and suggestions as to how to reduce it and manufacturing companies encourage recycling of packaging.

A focus on environmental performance developed initially to meet compliance requirements (Johnston and Smith 2001; Dias-Sadinha and Rijnders 2001) and scientific and societal interests (Kollk and Mauser 2002). The improved performance was demonstrated using physical measures alone, limiting the analysis of benefits and associated financial implications (Koelher 2001).

There have been few examples in the literature of data collected for sustainability reporting linked to performance evaluation and strategic alignment of organizational management systems; perhaps reflective of the limited exploration and understanding of system design and performance alignment within the mainstream management accounting literature, or the limited research on internal drivers for the development of sustainability management Adams and Frost (2008). 
Despite this, research on environmental management accounting (EMA), has found that adoption of EMA is limited for many companies. For example, (Frost and Wilmshurst 2000) observed that Australian companies were developing procedures to collate accounting data only for issues perceived to be of significant environmental importance. Similarly (Parker 2000) found that the environmental accounting techniques such as cost recognition were in a far more elementary stage than the application of environmental policies, management, impact statements, and audit. Prior research indicates that accounting for environmental issues may not be as advanced as other monitoring and measurement processes of an organizations' environmental management system.

Where environmental issues are regards as important, they are being managed, but accounting information is not being used in the decision-making process Adams and Frost (2008). (Schaltegger and Burritt 2000) suggesting that environmental management is based on the physical processes, inputs, and outputs. It is reflected in many of the environmental management accreditation schemes such as the ISO 14000 series and EMAS. If sustainability reporting is to lead to improvements in sustainability performance, organizations must seek to integrate both physical and financial performance indicators into various aspects of their management functions.

The inclusion of data on ethical, social, environmental and economic information into decision-making processes is a significant progression for an organization Koehler (2001). Without consideration of such data, it's hard to see how organizations can improve their sustainability performance. To assist decisionmaking and improve sustainability performance, KPIs measuring financial, physical and even attitudinal aspects of performance must be used, not only as a record of past performance, but also as a means of evaluating risk, developing plans and determining performance-based rewards. Similarly, possible future impacts of particular decisions should be calculated.

\section{3-2. Conceptual framework: SMAS and sustainable decision-making}

The key independent variables in this study are SMAS and CAS and their possible interaction. The underlying relationship between the SMAS and CAS are illustrative in figure (1). The figure illustrates that sustainable cost information could influence sustainable decision-making differently under different company $\mathrm{s}^{\prime}$ accounting system. There could also be an interaction effect. 


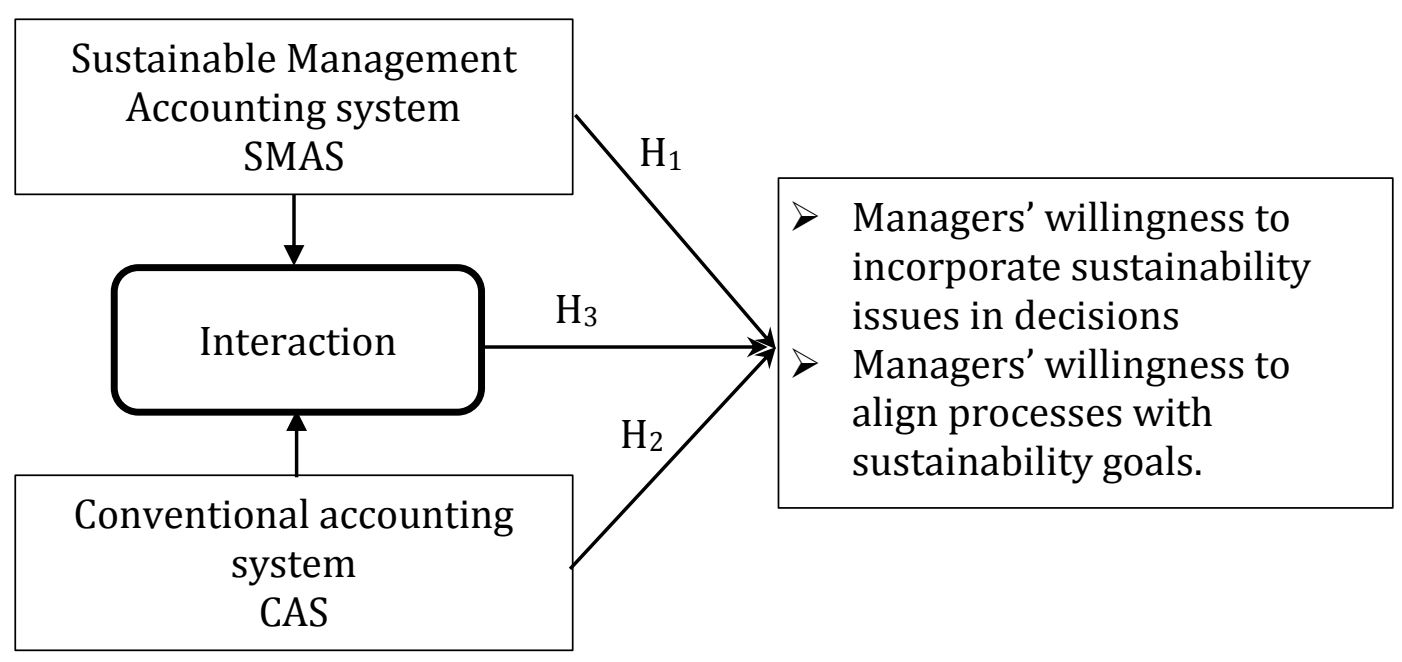

Figure (1): Conceptual Framework

Also, the relationship could depend upon personal characteristics of different managers involved, so it is important to include a range of managers in any empirical testing. The following section discusses the first independent variable of this study.

\section{A Consistent System of Sustainable Management Accounting}

Our purpose in developing a consistent system of sustainable management accounting is assisting companies in its pursuit of higher levels of maturity in sustainable development process. The outcomes of applying sustainability-related management accounting tools can enhance sustainable decision making by providing data that allow more precise identification of tangible and intangible costs for sustainable environment and social activities (internal and external) and identify resource-intensive activities. In the figure (2) the relationships with the flow scheme from flow sustainable management accounting tools are represented by broken arrows.

The introduction of sustainable development projects impacts on the costs and benefits of the activities within the firms, which are measured by sustainable investment methods. (Reverte 2016) demonstrates that creating a business case for sustainability requires a good understanding of links between non-monetary social and environmental activities on the one hand, and business or economic success on the other. The core question, and the basis for any business case for sustainability is how profit resulting from increased social and environmental activities can be identified and managed. So, management needs to assess appropriately the economic value created by innovative environmentally friendly projects.

The influences on the environment are caused by emissions, raw materials consumption, etc., which emanate from a company and its products. Many of these impacts on the environment can be prevented by means of environmental protection 
measures. To identify and subsequently analysis companies' environmental protection costs, a distinction is made between various types of environmental protection measures (production-related, process-integrated, end-of-pipe, etc.). These measures cause environmental protection costs, which are together with emission levies and other payments, internal environmental sustainability-related costs. Distinct from internal costs, external costs must be borne by third parties or society due to the environmental damage, which is caused. It includes, for example, damage to buildings or health, or a reduction in usefulness such as the loss of recreational areas. One of the objectives of environmental politics is to structure the relationship between external and internal costs in such a way that use for the whole of society is optimized (Loew 2013).

Several important decisions may be made from applying activity-based management (ABM) for environmental sustainability (Malone 2015). First, decreasing production of any of products will not necessarily result in the reduction of short-term costs or emissions. Overtime, redesign of products and processes may be informed by the relative resource intensity of these products; however, no short-term gains are likely to result from shifts in product mix, as allocations would simply shift among products, not be eliminated. Second, in the long term, where resource changes can be accomplished and environmental costs -both financial and physical - may be avoided, one must take into account the marginal product of the environmental resources being consumed. Finally, by examining the resource intensity concerning indirect physical environmental costs, a firm can more effectively plan resource allocations, plan product mixes, and make design changes with a better understanding of the implications for changes in physical environmental resource consumption. Applying this methodology in the context of environmental sustainability provides the firm better information with which to plan strategic initiatives and responses to environmental demands (e.g., regulatory pressures).

According to the well-known interpretation of the original definition given in the Brundtland Report, sustainability comprises three components: environment, economy, and social aspects. These components or 'pillars' of sustainability have to be properly assessed and balanced if a new product is to be designed or an existing one be improved. For the environmental part, there is already an internationally standardized tool: Life-Cycle Assessment (LCA). Life-Cycle Costing (LCC) is the logical counterpart of LCA for the economic assessment. LCC surpasses the purely economic accounting and cost calculation by taking into account the use- and end-oflife phases and hidden costs.

The life cycle perspective and cross-functional nature of target costing (TC) imply a vibrant process of product/process transformation with the goal of achieving a derived target cost. Indeed, a firm must plan carefully as far in advance as possible due to the nature of committed costs, both financial and environmental. The further 
into the life cycle of a product a firm advances, the higher the cost of adjusting costs (again, both financial and environmental) in response to changing environmental conditions (e.g., regulatory) Malone (2015). Rather than focusing solely on financial improvements; In TC for environmental sustainability targets can be set in physical terms with a TC methodology used to achieve those targets.

Effective sustainability management demands a more refined measurement, tracking, and accounting of the flow of physical materials, wastes, and energy, both within and outside the organizational boundaries. Material balance and energy balance accounts enable accurate identification of wastes or non-product outputs. These non-product outputs not only represent wasted resources but also are directly related to many of the adverse environmental impacts. Material and energy inputs also proxy for environmental and social impacts from an extraction of resources Marelli (2013).

The physical accounting side of material and energy flow cost accounting provides the needed information on the amounts of flows of energy, water, materials and wastes to assess these costs. The goal is to track material costs of product outputs, materials costs of non-product outputs, waste and emission control costs, prevention and other environmental management costs, research and development costs, and other less tangible costs Joshi and Krishnan(2010).

(Seuring and Muller 2008) emphasis the pressures that a focal company in a supply chain can bring to bear on its suppliers in relation to the provision of reliable data about environmental and social issues. The focal company can dominate the suppliers, or it can work to build up a trusting relationship. It has the power to make suppliers provide credible data or else lose their supply contracts, although the presence of power does not necessarily mean that it has to be used. Given a singular lack of government involvement in sustainable supply chain relationships in practice, a focal company can dictate that a specific method of measurement and reporting must be used by its suppliers, and then by their suppliers further upstream, etc. Suppliers can be required to provide information on their sustainability, which is subject to direct oversight, and audit (or assurance) as it is obtained by employees of the focal company. For such a purpose, the requirements could be (1) those prespecified by the focal company, based on its own standards; or (2) based on wellaccepted voluntary standards such as ISO 14001 for environmental management issues or SA 8000 and ISO 26000 for social matters; or (3) standards based on global best practice as a benchmark for information quality. The important dimension in the sustainable supply chain: how eco-efficiency, eco-effectiveness, and eco-equity are to be measured.

Balanced Scorecard (BSC) and its new model "Sustainability Balanced Scorecard"(SBSC) are adopted to formulate the mission and strategy towards sustainable development into tangible objectives and measures in a balanced way. 
Furthermore, the identified key factors and measures will be used as benchmarks to control the sustainability performance (Epstein and Wisner 2001; Figge et al. 2002). SMA tools will aim to collect and provide all decision-relevant information both internal and external and track opportunity costs and shadow costs. Ideally, SMAS will become an integral part of the sustainable performance measurement system (SPMS) and provide timely and accurate data for making superior decisions. On the other side, incorporating of environmental and social costs routinely into decisions can play an important role in avoiding sub-optimal decisions regarding regulatory compliance, cost-reduction, and efficiency improvement, product mix and pricing decision, risk management and product design, and help the firm to obtain product market differentiation. Therefore, based on the methodology of the SBSC with the help of SMA tools, a new model SPMS can be developed to encompass multi-aspects such as social, economic, and environmental issues. 

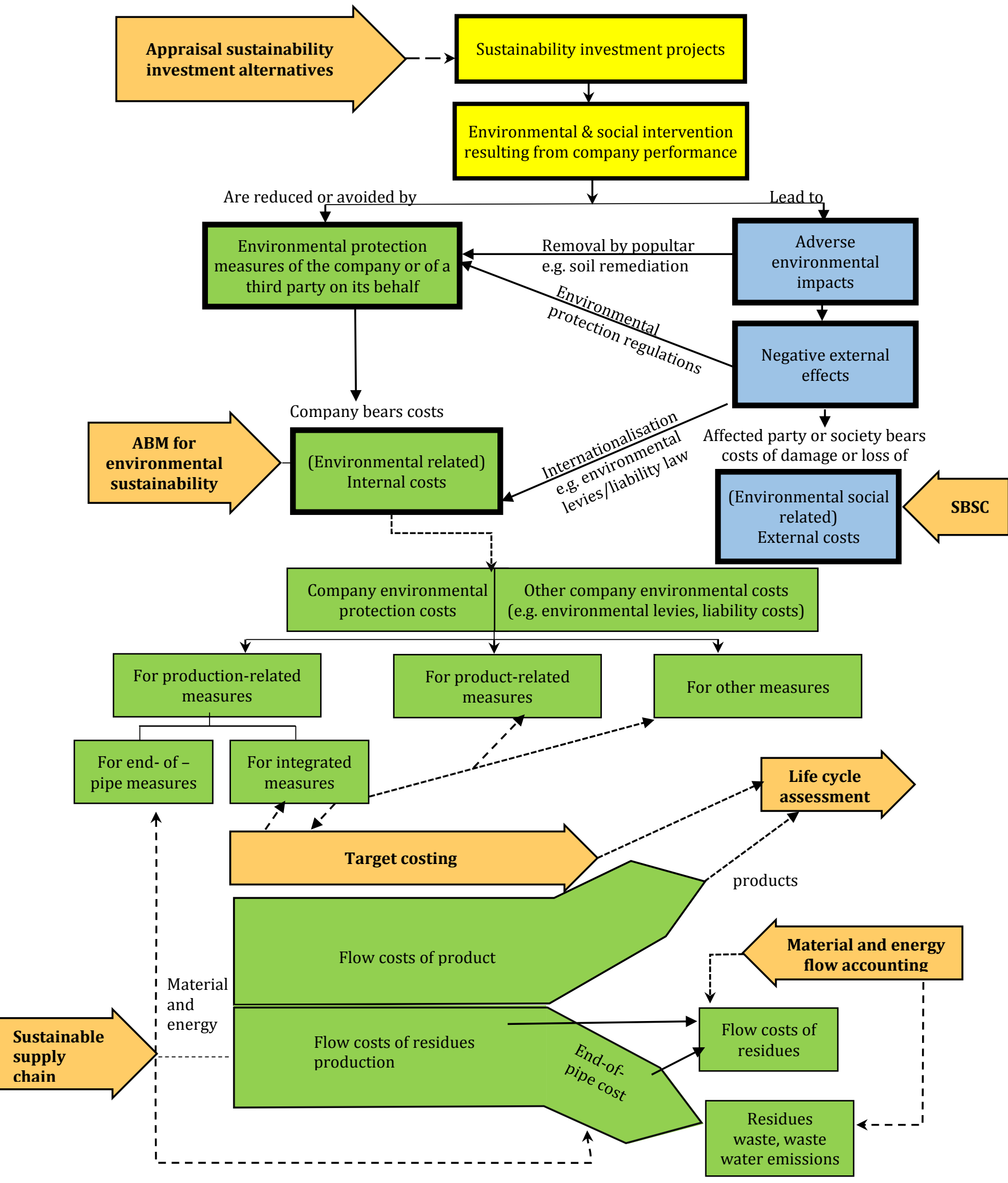

Figure (2): A consistent system of sustainable cost management Source: [Adopted from Loew (2003) with the edition of the researcher] 


\section{3-3. Research questions and hypothesis development}

The study seeks to provide empirical evidence about two research questions:

1. Does the use of the consistent system SMA influence both of the willingness of managers to include environmental and social considerations in their major sustainable decisions and to align their processes with sustainability goals compared with the use of the conventional accounting systems?

2. Is there any link between the use of the consistent system of SMA and the conventional accounting system, which has effect on the managers environmental and social decisions?

These research questions lead to the development of the following six hypotheses expressed in the null form:

$\mathrm{H}_{1 \mathrm{a}}$ : A manager's willingness to incorporate environmental and social considerations in major sustainable decisions is not affected by the use of the consistent system of SMA.

$\mathrm{H}_{1 \mathrm{~b}}$ : A manager's willingness to align their processes and activities with sustainability goals is not affected by the use of the consistent system of SMA.

$\mathrm{H}_{2 \mathrm{a}}$ : A manager's willingness to incorporate environmental and social considerations in major sustainable decisions is affected by the use of a conventional financial, cost and management accounting system.

$\mathrm{H}_{2 \mathrm{~b}}$ : A manager's willingness to align their processes and activities with sustainability goals is affected by the use of a conventional financial, cost and management accounting systems.

$\mathrm{H}_{3 \mathrm{a}}$ : The nature of the consistent system of SMA in combination with the conventional accounting system has no effect on the willingness of a manager to include environmental and social considerations in major sustainable decisions.

$\mathrm{H}_{3 \mathrm{~b}}$ : The nature of the consistent system of SMA in combination with the conventional accounting system has no effect on the willingness of a manager to align their processes with sustainability goals.

\section{Methodology}

The paper uses an experimental design study. The advantage of such an approach is the ability to manipulate the variables of interests to measure in a direct way the potential impacts. (Trotman1996) suggests that such an approach is useful for examining the main and interaction effects, as well as for controlling for confounding variables by building a single design. However it has to be recognized that in an experiment participants are not making real world sustainable decisions and consequently the external validity of the results can be called into question. Unlike surveys that capture attitudes, decision experiments measure behavior.

The advantage with decision experiments of course is that while they do measure changes in behavior, they do so under controlled and hypothical conditions which 
provide greater internal validity. The extent to which such behavior would be repeated in real decision situations is always opening to debate and debate over the trade-off between internal and external validity remains ongoing.

In short, the level of confidence that can be placed on the experimental results depends to some extent on how well the experimental conditions model the actual decision setting being emulated (Milne and Patten 2002).

Dependent Variables:

Dependent variable (1): Managers willingness to incorporate environmental and social considerations in major sustainable decisions.

Dependent variable (2): Managers willingness to align their processes and activities with sustainability management goals (eco-efficiency, socio-efficiency, and ecoJustice)

We conducted an experimental study of a sample of large companies operating in Egypt, including companies listed on the Egypt stock exchange and foreign subsidiaries. Participants in the decision experiment were a variety of managers engaged in overall company activities, thereby enhancing the internal validity of the study.

The managers included were randomly selected from seven different categories in the supply chain: (1) Management/administration, (2) Production, (3) Finance/ accounting/taxation, (4) Occupational health, safety and environment, (5)Marketing, human resources and external affairs, (6)Project management / technical consultants, and (7)Others.

Managers from 48 companies were available for this study. Industrial companies represented 56\% (27) of the sample, service companies represented 25\% (12), and distribution companies totaled 19\% (9). Two manger were chosen from each of the 48 companies and this gave a total of 96 manages available for inclusion in the experiment. Mangers, giving a response rate of $50 \%$, retuned 48 surveys.

We asked respondents about some demographic (contingency) variables:

1. Whether or not the company is listed on a stock exchange?;

2. The sector (industrial, service, and distributional);

3. What is the age in years?;

4. How long work experience in years?;

5. The number of years works experience in working at the field environmental \& social activities;

6. The number of years work experience in the decision-making context. 
Descriptive data are shown in the table (1).

1) Company's list or not listed on stock market n (\%)

Listed on sock market

$12(25 \%)$

Not listed on sock market

$36(75 \%)$

2) Company's sector $n(\%)$

Industrial companies

$27(56 \%)$

Service companies

$12(25 \%)$

Distribution companies

3) Average (S.D.) age in years

$9(19 \%)$

$44.6(9.28)$

4) Average (S.D.) work experience in years

$20.7(9.73)$

5) Environmental \& Social related work experience n (\%)

Yes

$30(63.5)$

No

$18(36.5)$

6) Decision-making related work experience $\mathrm{n}(\%)$

Yes

No

Table (1) Descriptive data

\section{4-1. Experimental Design}

The experiment was based on a $2 \mathrm{X} 2$ between-subjects full factional design. It used a within-subject comparison of internal versus external factors that influence management behavior in relation to the incorporation of environmental and social considerations into sustainable decision making. Participants were randomly allocated to one of four treatment groups, as shown in the table (2).

The experimental material included a general description of the purpose of the study and assured participant confidentiality. The experiment task comprised a vignette that was based on one example of sustainable decisions (capital investment decisionmaking to introduce new product-line technology) at the hypothetical XYZ Company Ltd.

After reading the randomly allocated case materials the participants were asked to provide their options in statements relating to three broad areas in the questionnaire. (1) Managers' views towards integrating environmental and social considerations into a company's sustainable decisions and aligning their processes and activities with sustainability goals within the context of a consistent system of SMA (Part A in the appendix);

(2) Managers' views towards the use of conventional financial, cost and management accounting system to enhance sustainable decision making (Part B in the appendix); and

(3) Managers' views towards the use of sustainability-related management accounting tools in identifying tangible and intangible costs and benefits for 
sustainable environmental and social activities in the context of both SMAS and CAS (Part $\mathrm{C}$ in the appendix).

For all statements, the participants were asked to respond on a five-point Likert scale that was anchored by "strongly disagree" (1) and "strongly agree" (5).

After completing these tasks and before handing in their responses, participants answered questions designed to check for manipulation and demographics as well as signing the letter of consent for this research in line with ethical procedures. Initial results from the survey are outlined in the following section.

\begin{tabular}{|c|c|c|}
\hline \multirow{2}{*}{ Sustainability decisions aid } & \multicolumn{2}{|c|}{ Company's accounting system } \\
\cline { 2 - 3 } & $\begin{array}{c}\text { Sustainable Management } \\
\text { Accounting System }\end{array}$ & $\begin{array}{c}\text { Conventional } \\
\text { Accounting System } \\
\text { (CAS) }\end{array}$ \\
\hline Use of tangible and intangible cost \& & Cell 1 & Cell 2 \\
benefits for sustainable environmental & $(\mathrm{X} 1)$ & $(\mathrm{X} 2)$ \\
and social activities & & Cell 3 \\
\hline No use of sustainable cost information & Cell 4 & (X3) \\
\hline
\end{tabular}

Table (2): Experimental design layout (Note: The experiment involves a multivariate

$$
\text { (2X2) design }
$$

\section{4-2. Results}

In this section correlation between dependent variables and some demography (contingency) variables, the comparison test of dependent variables by demography (contingency) variables, and hypothesis testing are examined in turn.

\section{Correlation and comparison test analysis}

The results of correlation analysis between the dependent variables and some demography (contingency) variables are reported in the table (3). The results show that environmental \& social work experience and decision making work experience are significantly correlated to the dependent variable (1): "manages' willingness to incorporate environmental \& social considerations in the main sustainable decisions."

Age, work experience, environmental \& social work experience, and decisionmaking work experience are significantly correlated with dependent variable (2): "managers' willingness to align their processes and activities with sustainability goals." These variables were next included in the ANCOVA model as covariates.

Age was negatively correlated with the dependent variable 2, indicating that the older the manager, the lower the willingness to align processes and activities with sustainability goals. 
Work experience, environmental \& social work experience, and decision-making work experience were positively correlated with the dependent variable 2 , indicating that the longer the work experience, the longer environmental \& social work experience, and the longer decision making-working experience, the greater the willingness to align processes and activities with sustainability goals.

In the table (4) results show that managers in the companies listed on the stock market are more willing to incorporate environmental \& social considerations in sustainability decisions and to align their processes with sustainability goals.

Also, the managers in industrial companies are more willing to incorporate environmental \& social considerations in sustainability decisions and to align their processes with sustainability goals than both of service and distribution companies.

\begin{tabular}{|c|c|c|c|c|}
\hline \multirow[b]{2}{*}{ Dependent variables } & \multicolumn{4}{|c|}{ Demography (contingency) variables } \\
\hline & Age & $\begin{array}{c}\text { Work } \\
\text { experience }\end{array}$ & $\begin{array}{c}\text { Envoi. \& } \\
\text { Social } \\
\text { work } \\
\text { experience }\end{array}$ & $\begin{array}{c}\text { Decision- } \\
\text { making } \\
\text { work } \\
\text { experience }\end{array}$ \\
\hline Dependent variable (1): & $.192^{*}$ & .2 & $.203^{\mathrm{b}}$ & $.243^{\mathrm{b}}$ \\
\hline $\begin{array}{l}\text { Managers' willingness to incorporate } \\
\text { environmental and social } \\
\text { considerations in major sustainable } \\
\text { decisions }\end{array}$ & $(.071)$ & $(.057)$ & $(.047)$ & $(.018)$ \\
\hline Dependent variable (2): & $-.322^{\mathrm{a}}$ & $.255^{\mathrm{b}}$ & $.220^{\mathrm{b}}$ & $.274^{\mathrm{a}}$ \\
\hline $\begin{array}{l}\text { Managers' willingness to align their } \\
\text { processes and activities with } \\
\text { sustainability cost management goals }\end{array}$ & $(.004)$ & $(0.019)$ & $(.033)$ & $(.007)$ \\
\hline \multicolumn{5}{|c|}{ a: Correlation is significant at the 0.01 level (2-tailed) } \\
\hline \multicolumn{5}{|c|}{ b: Correlation is significant at the 0.05 level (2-tailed) } \\
\hline
\end{tabular}

Table (3): Correlation between dependent variables and some demography (contingency) variables 
Table (4) Comparison test of dependent variables by demography (contingency) variables

\begin{tabular}{|c|c|c|c|c|c|c|c|c|c|}
\hline \multirow[b]{2}{*}{ Demography (contingency) variable } & \multirow[t]{2}{*}{$\mathbf{N}$} & \multicolumn{4}{|c|}{ Dependent variable (1) } & \multicolumn{4}{|c|}{ Dependent variable (2) } \\
\hline & & $\begin{array}{c}\text { Mean } \\
\text { level }\end{array}$ & S.D. & $\begin{array}{c}\text { Mean } \\
\text { Difference }\end{array}$ & P-value & $\begin{array}{c}\text { Mean } \\
\text { level }\end{array}$ & S.D. & $\begin{array}{c}\text { Mean } \\
\text { Difference }\end{array}$ & P-value \\
\hline 1b Not listed on stock market & 36 & 1.65 & 0.82 & 0.32 & $0.037 *$ & 1.35 & 1.19 & 0.57 & $0.004^{*}$ \\
\hline 2a Industrial Companies & 27 & 1.98 & 1.1 & 0.38 & $0.012^{*}$ & 1.95 & 1.14 & 0.4 & $0.03 *$ \\
\hline 3b Distribution Companies & 9 & 1.42 & 0.55 & 0.56 & $0.009^{*}$ & 1.2 & 0.5 & 0.75 & $0.01 *$ \\
\hline
\end{tabular}

* Significant differences at level $\alpha=0.05$ 
Table (5) Dependent variables 1: Managers' willingness to incorporate environmental and social considerations in the main sustainable decisions (managers are willing to incorporate ecological and social considerations in their major sustainable decisions in your opinion (strongly disagree -1 ; strongly agree-5))

\begin{tabular}{|l|c|c|c|c|c|}
\hline \multicolumn{1}{|c|}{ Panel A: Test of between-subjects effects } \\
\begin{tabular}{|l|c|c|c|c|}
\hline \multicolumn{1}{|c|}{ Sypes III sum } \\
of squares
\end{tabular} & Df & Mean square & F & Sig. \\
\hline 1- Covariates: & 0.018 & 1 & 0.018 & 0.022 & 0.83 \\
Envoi. \& Soc. work experience & 6.452 & 1 & 6.452 & 7.781 & $\mathbf{0 . 0 0 2}$ \\
Decision making work experience & & & & & \\
& & & & & \\
2- Main effects: & 7.245 & 1 & 7.245 & 9.154 & $\mathbf{0 . 0 0 4}$ \\
SMAS (1) & 1.552 & 1 & 1.552 & 2.323 & 0.14 \\
CAS (2) & & & & & \\
& & & & & \\
3- Interaction effect: & 0.055 & 1 & 0.055 & 0.79 & 0.757 \\
SMAS * CAS (1*2) & 33.05 & 42 & 0.787 & & \\
Error & 41.95 & 47 & & & \\
Corrected Total &
\end{tabular}

$\mathrm{R}$ squared $=0.212$ (Adjusted $\mathrm{R}$ squared $=0.168$ )

\begin{tabular}{|c|c|c|c|c|}
\hline \multicolumn{5}{|c|}{ Panel B: Means (SDs) } \\
\hline \multirow{2}{*}{$\begin{array}{l}\text { Managers' willingness to incorporate } \\
\text { environmental and social considerations in } \\
\text { major sustainable decision }\end{array}$} & \multicolumn{2}{|c|}{ Company's accounting system } & \multirow{2}{*}{$\mathbf{F}$} & \multirow{2}{*}{ P-value } \\
\hline & SMAS & CAS & & \\
\hline $\begin{array}{l}\text { Use of tangible and intangible } \\
\text { cost \& benefits for sustainable } \\
\text { Environmental and social activities }\end{array}$ & $\begin{array}{c}\mathrm{X} 1 \\
6.33(0.79) \\
(\mathrm{N}=14)\end{array}$ & $\begin{array}{c}\mathrm{X} 2 \\
5.22(0.49) \\
(\mathrm{N}=9)\end{array}$ & 7.52 & 0.003 \\
\hline $\begin{array}{l}\text { Non use of sustainable cost } \\
\text { information }\end{array}$ & $\begin{array}{c}\mathrm{X} 4 \\
4.85(0.82) \\
(\mathrm{N}=13)\end{array}$ & $\begin{array}{c}\mathrm{X} 3 \\
4.63(1.3) \\
(\mathrm{N}=12)\end{array}$ & 1.427 & 0.062 \\
\hline
\end{tabular}


Table (6) Dependent variables 2: Managers' willingness to align their processes and activities with sustainability goals (The company should align their processes with sustainability goals (strongly disagree-1; strongly agree-5))

\begin{tabular}{|l|c|c|c|c|c|}
\hline \multicolumn{5}{|c|}{ Panel A: Test of between-subjects effects } \\
\hline \multicolumn{1}{|c|}{ Source } & $\begin{array}{c}\text { Types III } \\
\text { sum of } \\
\text { squares }\end{array}$ & Df & $\begin{array}{c}\text { Mean } \\
\text { square }\end{array}$ & F & Sig. \\
\hline 1. Covariates: & .145 & 1 & .145 & .182 & 0.66 \\
Age & 6.942 & 1 & 6.942 & 8.73 & $\mathbf{0 . 0 0 3}$ \\
Total work experience & 1.652 & 1 & 1.651 & 2.23 & 0.14 \\
Envoi. \& Soc. & 6.649 & 1 & 6.649 & 8.944 & $\mathbf{0 . 0 0 4}$ \\
work experience & & & & & \\
Decision making- & & & & & \\
work experience & & & & & \\
& & & & \\
Main effects: & 1.38 & 1 & 1.38 & 1.73 & .19 \\
SMAS (1) & & & & & \\
CAS (2) & 0.009 & 1 & 0.009 & 0.01 & 0.94 \\
Interaction effects: & 35.008 & 41 & 0.853 & & \\
SMAS * CAS (1*2) & 41.45 & 47 & & & \\
Error & & & & \\
Corrected Total &
\end{tabular}

R Squared $=0.155$ (Adjusted R Squared $=0.098$ )

\begin{tabular}{|c|c|c|c|c|}
\hline \multicolumn{5}{|c|}{ Panel B: Means (SDs) } \\
\hline \multirow{2}{*}{$\begin{array}{l}\text { Managers' willingness to align } \\
\text { their processes with } \\
\text { sustainability goals }\end{array}$} & \multicolumn{2}{|c|}{$\begin{array}{c}\text { Company's accounting } \\
\text { system }\end{array}$} & \multirow[t]{2}{*}{$\mathbf{F}$} & \multirow{2}{*}{$\begin{array}{c}\text { P- } \\
\text { value }\end{array}$} \\
\hline & SMAS & CAS & & \\
\hline $\begin{array}{l}\text { Use of tangible and intangible } \\
\text { cost \& benefits for sustainable } \\
\text { environmental and social activities }\end{array}$ & $\begin{array}{c}\mathrm{X} 1 \\
5.16(0.62) \\
(\mathrm{N}=14)\end{array}$ & $\begin{array}{c}\mathrm{X} 2 \\
5.04(0.72) \\
(\mathrm{N}=9)\end{array}$ & 1.84 & 0.065 \\
\hline $\begin{array}{l}\text { Non use of sustainable cost } \\
\text { information }\end{array}$ & $\begin{array}{c}\mathrm{X} 4 \\
4.17(0.76) \\
(\mathrm{N}=13)\end{array}$ & $\begin{array}{c}\mathrm{X} 3 \\
4.08(0.79) \\
(\mathrm{N}=12) \\
\end{array}$ & 1.42 & 0.071 \\
\hline
\end{tabular}

\section{Hypothesis Testing}

To test the six hypotheses, within subjects ANCOVA was applied for the two dependent variables: (1) managers' willingness to incorporate environmental and social considerations in the main sustainable decisions, and (2) managers' willingness to align their processes and activities with sustainability goals. The results can be found in tables (5) and (6). Comments on the results of testing each hypothesis follow. 
Results in the table (5) Panel A indicates that a consistent system of sustainability management accounting (SMA) have a statistically significant positive impact on the willingness of managers to incorporate environmental \& social considerations in sustainable decisions, the null hypothesis, $\mathrm{H}_{1 \mathrm{a}}$, can be rejected.

Results in the table (6) Panel A indicates that the consistent system of sustainable management accounting (SMAS) have a statistically significant positive impact on the willingness of managers to align their processes with sustainability goals. The null hypothesis, $\mathrm{H}_{1 \mathrm{~b}}$, can be rejected.

The conclusion is that there is an impact of SMAS on the willingness of this diverse sample of managers, from different companies sectors, to address environmental \& social issues in the main sustainable decisions.

Results in the table (5) Panel A indicates that conventional accounting system (CAS) does not have a statistically significant positive impact on the willingness of managers to incorporate environmental \& social issues in the main sustainable decisions. The null hypothesis, $\mathrm{H}_{2 \mathrm{a}}$ can be rejected.

Results in the table (6) Panel A indicates that conventional accounting system (CAS) does not have a statistically significant positive impact on the willingness of managers to align their processes with sustainability goals. $\mathrm{H}_{2 \mathrm{~b}}$ can be rejected. Consistent results were obtained for the non-significant impact of conventional accounting system (CAS) on the willingness of this diverse sample of managers, from different companies sectors, to align processes and activities with sustainability goals.

Results in tables (5) and (6) Panel A indicate that there is no significant interaction effect between SMAS and CAS. The null hypotheses $\mathrm{H}_{3 \mathrm{a}}$ and $\mathrm{H}_{3 \mathrm{~b}}$ hold.

The final stage of analysis is to examine the results when two alternatives of company's accounting systems, SMAS and CAS and two sustainable information ways, use of and non-use of tangible and intangible cost \& benefits for sustainable activities, are considered. Their results appear in tables (5) and (6) Panel B.

Panel B in the table (5) provides the means (standard deviations) of the scores for the managers' willingness to incorporate environmental \& social issues in the main sustainable decisions. The mean (standard deviation) score for the use of tangible and intangible cost \& benefits for sustainable activities in a consistent system of sustainable cost management is 6.33(0.79) as compared with 5.22(0.49) in a conventional accounting system $[\mathrm{X} 1>\mathrm{X} 2]$, but the difference is statistically significant $(\mathrm{F}=7.521, \mathrm{P}=0.003)$. The mean (standard deviation) for the non-use of sustainable cost information in SMAS is 4.85 (0.82) as compared with 4.63 (1.3) in a CAS $[\mathrm{X} 4>\mathrm{X} 3]$, but the difference is not statistically significant $(\mathrm{F}=1.427$, $\mathrm{P}=0.062$ ). 
This result reveals no difference between the impacts of both accounting system alternatives on managers' willingness to incorporate environmental \& social considerations in the main sustainable decisions in the case of alternative non-use of sustainable cost information.

Similar conclusions can be drawn from Panel B in the table (6) in respect of managers' willingness to align processes with sustainability goals. These results reveal that for both alternatives of accounting systems, the alternative of SMAS has a differential impact on the willingness of managers to align processes with sustainability goals [X1>X2 and X4>X3].

Panel B in the table (6) shows that the mean (Standard deviation) score in SMAS where tangible and intangible cost $\&$ benefits for sustainable activities is available is 5.16(0.62) as compared with $4.17(0.76)$ where it is not available [X1 > X4]. This difference is statistically significant $(\mathrm{F}=8.75, \mathrm{P}=0.004)$.

Likewise, the mean (standard deviation) score in a conventional accounting system (CAS) were tangible and intangible sustainable cost information is available is $5.04(0.79)$ as compared with $4.08(0.79)$ where it is not available [X2>X3]. This difference is statistically significant $(\mathrm{F}=3.66, \mathrm{P}=0.03)$.

This result reveals significant differences between situations where sustainable cost information is and is not available.

As before, similar conclusions can be drawn from Panel B in the table (6) in respect to managers' willingness to align processes with sustainability goals. These results reveal that for both alternatives of accounting systems the availability of sustainable cost information is linked with a greater willingness of managers to align processes with sustainability goals [X1>X4 and X2>X3].

\section{4-3. Manipulation checks}

To ensure that the difference a consistent system of SMAS and conventional accounting system (CAS) were perceived as being different by participants, four items (separate questions) were measured and a five-point Likert scale anchored at strongly disagree (1) and strongly agree (5) (Part D in the appendix). The scores of these four items were totaled to form the government/self score (theoretical range 4 to 20). A t-test indicated a significant difference between the two treatment groups $(\mathrm{t}=4.45, \mathrm{P}=0.000)$, 2-tailed test). The mean (standard deviation) for participants in the conventional accounting system treatment was 16.4 (2.3), and the mean (SD) for participants in the consistent system of SMA was 14.9 (4.3). A similar procedure was carried out to test the success of manipulation of the availability/non-availability of sustainable cost information for sustainable environmental and social activities. The mean (SD) for the availability of sustainability cost information was 15.5 (1.62), and for the non-availability of sustainability cost information, it was 14.9 (1.2). The results were significantly 
different $(\mathrm{t}=2.92, \quad \mathrm{P}=0.012)$, demonstrating that participants successfully differentiated both manipulations.

\section{Conclusions}

Given the considerations expressed in the review of the emerging stream of literature on SMAS and to illustrate the main unaddressed issues in this area of research as the research gap. We suggested a consistent system of SMAS, which could be used to study the research topic empirically. The original idea examined in this study is whether the availability of cost and benefits for sustainable environmental and social activities affects the willingness of managers to take sustainable considerations into account in their sustainable decisions and to align their processes with sustainability goals in the context of two alternatives company s' accounting systems. The evidence reported here reveals that when sustainability cost information is available to managers at various stages of the supply chain, they are more willing to take sustainable decisions and align their processes with sustainability goals. Also, SMAS has a positive impact on the willingness of managers to consider sustainability issues in their decisions and align their processes with sustainable goals.

We leverage these findings into a series of research questions to stimulate the interests of accounting academics for future accounting or interdisciplinary research in sustainability. These results have several implications for public policy in Egypt and accounting practice. Collectively, public policy setters like Egypt Stock Exchange need to be more collaborative with practicing accountants, academics, and other regulators. Egypt Stock Exchange is taking this approach in developing its reporting standards. The collective results should help practicing accountants better understand how to posses a unique ability to identify, capture, analysis, and communicate informational critical in linking strategy and sustainability activities.

These implications are bolstered when considering the findings in (Cohen et al. 2011, 2012) that voluntary disclosure of leading nonfinancial information (e.g., market share, innovation) are increasing in volume and are perceived as increasingly important by investors. However, firms vary widely on the nature, extent, and timing of reporting such information. As such, Cohen et al. (2012) argue that based on their results, more regulation and assurance for the reporting of nonfinancial information, including sustainability-related information, is needed. Nonfinancial measures promoted strategic integration through improved information for decision-making and increased internal awareness of value drivers. 
Also, considering the study of (Porter and Kramer 2011), unlike neoclassical economic theories of sustainability, the company does not confine an initiatives' value creation to the company's shareholders. If organizations think about sustainability initiatives in the same manner as their core business decisions, such initiatives cannot only be a source of competitive advantage and long-term value for shareholders, but also be highly appreciated by an organization' multiple stakeholders. Mostly, embedding sustainability issues into strategic decisions making creates long, shared stakeholder value through improved resource allocation.

Our study is subject to several limitations. First, including those typically associated with experimental methods, suggesting fruitful areas of future research using survey-based and exploratory research that would be beneficial to supplement our research by establishing attitude. Second, being related to data collection by obtaining the responses from various managers in the supply chain, this may have influenced the independent, dependent variables that were related to strategic decision-making. Finial limitation of this study is that all of the data were collected in Egypt. As management practices and business processes differ between countries, the limitation is the lake of knowledge as to the extent to which the current findings can be applied in other countries.

In sum, while all limitations are evident, none is unusual or unique to this study. Given the strong interrelationships clear in the findings, the results appear to be valid and meaningful. 


\section{References}

- Abrahamson, E., (1991), Managerial Fads and Fashions: the diffusion and rejection of innovations, Academy of Management Review, 16(3), 586-612.

- AccountAbility. (2008), AA1000 AccountAbility Principles Standard, London.

- Adams, C. A. (2002), Internal organizational factors influencing corporate social and ethical reporting. Beyond current theorizing, Accounting, Auditing and Accountability Journal, 15: 223-250.

- Adams C. A., and Frost G.R. (2008), Integrating Sustainability Reporting into Management Practices, Accounting Forum, 32: 288-302.

- Adams, C. A., and McNicholas, P. (2007). Making a difference Sustainability reporting, accountability and organizational change, Accounting, Auditing and Accountability Journal, 20:382-402.

- Adams, C. A., and Whelan, G. (2009), Conceptualising future change in corporate sustainability reporting, Accounting, Auditing and Accountability Journal, 22: 118-143.

- Ballou B., Gasey R., Grenier J., and Dan 1. H., (2012), Exploring the strategic integration of sustainability initiatives: opportunities for accounting research, Accounting Horizons, 26(2), 265-288.

- Bartolomes, M., Bennett, M., Bouma, J. J., Heydkamp, P., James, P. and Wolter, T., (2000), Environmental management accounting in European: Current practice and further potential, European Accounting Review, 9(1), 31-52.

- Bebbington, J., (2001), Sustainable development: a review of the international development, business and accounting literature, Accounting Forum, 25(2), 128157.

- Bebbington, J. (2007), Changing organizational attitudes and culture through sustainability accounting. In Unerman J., Bebbington, J. and B. O'Dwyer, (Editors), Sustainability Accounting and Accountability (pp.226-242). Routledge, London.

- Bennett, M., and James, P. (1998), The green bottom line: Environmental accounting for management: Current practice and future trends, Sheffield, England, Greenleaf pub. ,pp.61-85

- Birkin, F., and Woodward, D., (1997a), Management accounting for sustainable development part 5: accounting for sustainable development, Management Accounting (UK), 75(10), 52-54.

- Birkin, F., and Woodward, D., (1997b), Management accounting for sustainable development part 2: from economic to ecological efficiency, Management Accounting (UK), 75(7), 42-45.

- Bonacchi, M., and Rinaldi, L. (2007), Dartboards and clovers as new tools in sustainability planning and control, Business Strategy and the Environment, 16: 461-473. 
- Bouten, L., and Hooze' e, S. (2013), On the interplay between environmental reporting and management accounting change, Management Accounting Research, 24: 333-348.

- Burritt, R.L., Hahan, T., and Schaltegger, S., (2002), Towards a Comprehensive framework for Environmental Management Accounting- Links Between Business Actors and Environmental Management Accounting Tools, Australian Accounting Review, July, 12(2):39-50.

- Burritt, R. L. and Schaltegger, S. (2010), Sustainability Accounting and Reporting: Fad or Trend? , Accounting, Auditing and Accountability Journal, 23 (7), 829-846.

- Cho, C. H., and Caron M-Andree (2013), Accounting Tools for Environmental Management and Communication, In Mitchell F., Norreklit H. and Jakabsen M. (Editors), The Routledge Companion to Cost Management, (pp.515-530), Routledge Tylor and Friends Group, London.

- Cohen, J., L. Holder-Webb, L. Nath, and D. Wood, (2011), Retail investors' perceptions of the decision-usefulness of economic performance, governance and corporate social responsibility disclosures, Behavioral in Accounting, 23(1), 109129.

- Cohen, J., L. Holder-Webb, L. Nath, and D. Wood, (2012), Corporate reporting of non-financial leading indicators of economic performance and sustainability, Accounting Horizons, 26(1), 65-90.

- Deegan, C. (2002), The legitimizing effect of social and environmental disclosures A theoretical foundation, Accounting, Auditing and Accountability Journal, 15: 282-311.

- Dias-Sadinha, I., and Reijnders, L., (2001), Environmental performance evaluation or organizations: An evolutionary framework, Eco-Management and Auditing, 8, 71-79.

- Durdan, C., (2008), Towards a socially responsible management control system, Accounting, Auditing and Accountability Journal, 21, 671-694.

- Epstein, M. J., and Wisner, P. S. (2001), Using a balanced scorecard to implement sustainability, Environmental Quality Management, 2:1-10.

- Figge F. and Hahn T. (2013), Value drivers of corporate eco-efficiency: Management accounting information for the efficient use of environmental resources, Management Accounting Research, 24:387-400.

- Figge, F., Hahn, T., Schaltegger, S., and Wagner, M. (2002), The sustainability balanced scorecard Linking sustainability management to business strategy, Business Strategy and the Environment, 11(5): 269-284.

- Frost, G. R., and Wilmshurst, T. D., (2000), the adoption of environment-related management accounting: An analysis of corporate environmental sensitivity, Accounting Forum, 24(4), 344-365.

- Global Reporting Initiative (2011), G3.1, Available at (accessed October, 201 
1):http://www.globah'epor ting.org/Reporting Framework/G31 Guidelines/

- Gond, J.-P., Grubnic, S., Herzig, C., and Moon, J. (2012), Configuring management control systems: Theorizing the integration of strategy and sustainability, Management Accounting Research, 23: 205-223.

- Gray, R. H. (2002), The social accounting project and accounting organizations and society: Privileging engagement, imaginings, new accountings and pragmatism over critique? Accounting, Organizations, and Society, 27: 687-708.

- Gray, R. H. (2010), Is accounting for sustainability actually accounting for sustainability and how would we know? An exploration of narratives of organizations and the planet, Accounting, Organizations, and Society, 35: 47- 62.

- Gray, R. H., Kouhy, R., and Lavers, S. (1995), Corporate social and environmental reporting. A review of the literature and a longitudinal study of UK disclosure, Accounting, Auditing and Accountability Journal, 8: 47- 77.

- Henri, J.F., and Journeault, M. (2010), Eco-control: The influence of management control systems on environmental and economic performance, Accounting, Organizations, and Society, 35: 63-80.

- Jasch, C., (2006), How to perform an environmental management cost assessment in one day, Journal of Cleaner Production, 14, 1194-1213.

- Johnston, A., and Smith, A. (2001), The characteristics and features of corporate environmental performance indicators- A case study of the water industry of England and Wales, Eco-Management and Auditing, 8, 1-11.

- Joshi S., and Krishnan R., (2010), Sustainability Accounting Systems with A Managerial Decision Focus, Journal of Cost Management, Nov/Dec: 20-28.

- Koehler, D. A. (2001), Development in health and safety accounting at Baxter International, Eco-Management and Auditing, 8, 229-239.

- Kolk, A., and Mauser, A., (2002), The evolution of environmental management, from stage models to performance evaluation, Business Strategy and the Environment, 1, 14-31.

- Larrinaga-Gonzalez, C., and Bebbington, J. (2001), Accounting change or institutional appropriation? A case study of the implementation of environmental accounting, Critical Perspectives on Accounting, 12: 269-292

- Laufer, W. S. (2003), Social accountability and Corporate Greenwashing, Journal of Business Ethics, 43: 253- 261.

- Lehman, G., (2002), Global accountability and sustainability: research prospects, Accounting Forum, 26(3), 219-232.

- Loew T., (2003), Environmental Cost Accounting: Classifying and comparing Selected Approaches, In Bennett M., Rikhardsson P. M., and Schaltegger S., (Editors), Environmental Management Accounting-Purpose and Progress, (pp.4156), Springer Science and Business Media Dordrecht.

- Malone, D., (2015), Cost Management Tools for the Environmentally Sustainable 
Firm, Journal of Cost Management, March/April: 41-47.

- Marelli A., (2013), Environmental Cost Management for Green Production, In Mitchell F., Norreklit H. and Jakabsen M. (Editors), The Routledge Companion to Cost Management, (pp.320-341), Routledge Tylor and Friends Group, London.

- Milne, M. J., and Patten, D., M., (2002), Securing Organizational Legitimacy: an experimental decision case examining the impact of environmental disclosure, Accounting, Auditing and Accountability Journal, 15(3), 372-405.

- Neu, D., Warsame, H., and Pedwell, K. (1998), Managing public impressions: Environmental disclosures in annual reports, Accounting, Organizations and Society, 23: 265-282.

- Owen, D. L., (2008), Chronicles of wasted times? A personal reflection on the current state of, and future prospects for, social and environmental accounting research, Accounting, Auditing and Accountability Journal, 21(2): 240-267.

- Parker, L. D., (2000), Green strategy costing: early days, Australian Accounting Review, 10(1), 46-55.

- Parker, L. D., (2011), Twenty-one years of social and environmental accountability research: a coming of age, Accounting Forum, 35,1-10.

- Perego, P., and Hartmann, F. (2009), Aligning performance measurement systems with strategy: The case of environmental strategy, ABACUS, 45: 397 -428.

- Porter, M., and M. Kramer, (2006), Strategy and society: the link between competitive advantage and corporate social responsibility, Harvard Business Review (December), 78-92.

- Porter, M., and M. Kramer, (2011), Creating shared value: How to reinvent capitalism- and unleash a wave of innovation and growth, Harvard Business Review, (January-February), 62-77.

- Rebitzer, G. (2002), Integrating life-cycle costing and life-cycle assessment for managing costs and environmental impacts in supply chains, In S. Seuring and M. Goldbach (Editors), Cost management in supply chains (pp.128-146). Heidelberg: Physica-Verlag.

- Reverte, C. (2016), Corporate social responsibility disclosure and market valuation: evidence from Spanish listed firms, Review Management science, 10:411-435.

- Schaltegger, S., (1998), Accounting for eco-efficiency, In Nath, B., Hens, L., Compton, P., Devuyst, D. (Editors), Environmental Management in Practice, Vol.1, (pp.272-287), Routledge, London.

- Schaltegger, S., and Burritt R. L. (2000), Contemporary Environmental Accounting- Issues, Concepts and Practice, Taylor and Francis Publishing, pp.96102.

- Schaltegger S. and Wagner M., (2006), Integrative Management of Sustainability Performance, Measurement and Reporting, International Journal of Accounting, 
Auditing and Performance Evaluation, Vol. 3(1), 1-19.

- Seuring S., and Muller M., (2008), from a literature review to a conceptual framework for sustainable supply chain management, Journal of Cleaner Production 16: 1699-1710.

- Songini, L., and Pistoni, A. (2012), Accounting, auditing and control for sustainability, Management Accounting Research, 23: 202-204.

- Spence, C. (2007), Social and environmental reporting and hegemonic discourse, Accounting, Auditing and Accountability Journal, 20: 855-882.

- Stone, D., (1995), No longer at the end of the pipe, but still a long way from sustainability: a look at management accounting for the environment and sustainable development in the United States, Accounting Forum, 19(2-3), 95-110.

- Thomson, T., (2007), Mapping the terrain of sustainability accounting, In Unerman, J., Bebbington, J., O'Dwyer, B. (Editors), Sustainability Accounting and Accountability, (PP.19-36), Routledge, London.

- Trotman, K. (1996), Research methods for judgment and decision making studies in auditing, Melbourne: Coopers \& Lybrand.

- United Nations Conference on Trade and Development (1996), Incentives and disincentives for the adoption of sustainable development by transnational corporations, Geneva: United Nations.

- Wall F. and Greiling D., (2011), Accounting information for managerial decisionmaking in shareholder management versus stakeholder management, Review Management Science, 5: 91-135.

- World Business Council for Sustainable Development (2001), the business case for sustainable development, Geneva: World Business Council for Sustainable Development (WBCSD). 


\section{Case background}

\section{Appendix}

Sustainability framework or model of social, environmental, and economic performance offers a compelling opportunity to create enduring value for multiple stakeholders in the firm. We have developed the framework to aid companies in identifying, and integrating social, environmental, and economic impacts into corporate strategy and into management decisions to manage those impacts successfully and increase profitability.

Few business decisions impact a company's long-term capabilities and operational strategies as much as capital investment decisions and introducing new product because they influence innovation, productivity, costs, revenues, capacity availability, and quality. These decisions help to determine a company' competitive stance and long-term positioning.

Corporations commonly use techniques such as discounted cash flow (DCF) analysis to evaluate general investment projects. Such techniques incorporate both the time value of money and the need to earn competitive returns on capital investments. But they often do not use DCF analysis in sustainability projects. One of the primary reasons is the difficulty associated with the evaluation of social, environmental, and economic costs, benefits, risks, and the timings of costs and benefits. Only through the identification, measurement, and management of sustainability impacts can social, environmental, economic, and financial performance be improved and value created.

Let a fictitious company maker of clothing and gear for the outdoor enthusiast, is known for its focus on environmental and social issues in its manufacturing and company strategy. The company study to introduce new product line technology. One new product, a wool shirt, would be made from wool from New Zealand, processed in a factory in Japan, sewn in Los Angeles, and then package in Reno for distribution to retail locations worldwide.

\section{Part A}

First: based on case background, in your opinion how much you agree that the following environmental and social inputs which provided by a consistent system of sustainability of management accounting (SMAS) should be incorporated into capital investment decision-making to introduce new product-line technology for manufacturing a wool shirt product? 
(1) Strongly disagree;

(2) Disagree;

(3) Biased;

(4) Agree;

(5) Strongly agree.

\begin{tabular}{|c|c|c|c|c|}
\hline $\begin{array}{c}\text { Environmental and social inputs into capital } \\
\text { investment decisions-making }\end{array}$ & $\mathbf{1}$ & 2 & 3 & 4 \\
\hline $\begin{array}{l}\text { 1- Full costs of production, including associated } \\
\text { environmental and safety costs. } \\
\text { 2- Potential liabilities from safety hazards to workers } \\
\text { and the community at large; } \\
\text { 3- Health and ecological risk arising from operational } \\
\text { emissions of regulated and unregulated pollutants and } \\
\text { hazardous materials; } \\
\text { 4- Product safety-related issues. } \\
\text { 5- Relative sustainability performance of alternative } \\
\text { design choice. } \\
\text { 6- Social economic impact: amount of weight for } \\
\text { each impact category such as GHG acid rain and so } \\
\text { on and each harmful substance such as carbon } \\
\text { dioxide (CO }{ }_{2} \text { ) nitrogen oxide (NOx) } \\
\text { 7- Amount of weight of harmful substance. } \\
\text { 8- Value generated and distribution to each } \\
\text { stakeholder. } \\
\text { 9- Sharing resources and risks to generate value. } \\
\text { 10- Annual expenditures incurred on customer } \\
\text { awareness initiatives. } \\
\text { 11- Amounts of total contributions/donations to } \\
\text { charitable initiatives (health, education etc.). } \\
\text { 12- Non-financial benefits to employees (including } \\
\text { housing, health care, and stock options, etc.). } \\
\text { 13- Policy on code of conduct for protecting human } \\
\text { rights. } \\
\text { 14- Funds committed for research and development } \\
\text { on effective energy conservation efforts. } \\
\text { 15- Cost of social training per employee. }\end{array}$ & & & & \\
\hline
\end{tabular}


Second: determine the extent to which the processes and activities in the company should be aligned with the following sustainability goals to achieve sustainability strategy.

(1) Strongly disagree;

(2) Disagree;

(3) Biased;

(4) Agree;

(5) Strongly agree.

\begin{tabular}{|c|c|c|c|c|}
\hline Sustainability goals & 1 & 2 & 3 & 4 \\
\hline $\begin{array}{l}\text { 1-prohibit the use of child, forced, or involuntary } \\
\text { labour. } \\
\text { 2- Ensure all customers are treated fairly and } \\
\text { consistently } \\
\text { 3- Support and obey laws that prohibit discrimination } \\
\text { everywhere in places in the company does business. } \\
\text { 4- Develop effective processes to prohibit the } \\
\text { uncontrolled release of pollutants (e.g., wastewater, } \\
\text { sulphur dioxide, and nitrous oxide). } \\
\text { 5- Actively investigate regulatory and safety-related } \\
\text { issues with products, and promptly remove from all } \\
\text { avenues if necessary. } \\
\text { 6- save tons of paper and plastic through packaging } \\
\text { and shipment redesigns, reducing landfill waste. } \\
\text { 7- increase company recycling rate. } \\
\text { 8- Use responsible sales and marketing to carry clear } \\
\text { information to the customers. } \\
\text { 9- Realize throughput improvement, cycle time } \\
\text { reduction, and improvement in on-time delivery } \\
\text { because of manufacturing improvements at company } \\
\text { facilities. } \\
\text { 10- Incorporate green design standards and building } \\
\text { concepts into the construction of company facilities. } \\
\text { 11- Actively promote gender equality and diversity in } \\
\text { the workplace. } \\
\text { 12- Perform self-audits to ensure compliance with } \\
\text { company-wide standards. }\end{array}$ & & & & \\
\hline
\end{tabular}




\section{Part B}

Based on case background, in your opinion how much you agree that financial, cost information is the only factors (inputs), which should be incorporated into capital investment decision-making to introduce new product-line technology for manufacturing a wool shirt product?

(1) Strongly disagree;

(2) Disagree;

(3) Biased;

(4) Agree;

(5) Strongly agree.

\begin{tabular}{|c|c|c|c|c|c|}
\hline $\begin{array}{l}\text { Financial and cost information inputs into capital } \\
\text { investment decisions-making }\end{array}$ & $\mathbf{1}$ & 2 & 3 & 4 & 5 \\
\hline $\begin{array}{l}\text { 1- Economic value added= operating } \\
\text { profit }- \text { (invested capital } \times \text { opportunity } \\
\text { cost for invested capital) } \\
\text { 2- Achieved net profit/ target net profit } \\
\text { 3- Total actual sales / total planned sales } \\
\text { 4- Cash inflows in the coming five years } \\
\text { 5- Cash outflows in the coming five years } \\
\text { 6- Acquisition costs of assets. } \\
\text { 7- Insurance costs against risk. } \\
\text { 8- Operating and capital expenditures. } \\
\text { 9- Value of investing in technology. } \\
\text { 10- Reserves for expected risks }\end{array}$ & & & & & \\
\hline
\end{tabular}

\section{Part C}

Incorporating cost management information derived from full social and environmental cost accounting or a life-cycle assessment can help managers identify and quantify impacts related to both current and future operations and current and future risks. Determining the full range of investment' sustainability impacts is an important step toward better management decision-making. Once identified, the impact of these costs on company' activities, processes, products, and services can be analyzed using available tools.

How much would you agree that the using of the following sustainabilityrelated management accounting practices (tools) help to identify and measuring tangible and intangible costs and benefits for sustainable environmental and social activities in the context of both a consistent system 
of sustainability of management accounting (SMAS) and the conventional accounting system (CAS)?

(1) Strongly disagree;

(2) Disagree;

(3) Biased;

(4) Agree;

(5) Strongly agree.

\begin{tabular}{|c|c|c|c|c|c|c|c|c|c|c|}
\hline \multirow[t]{2}{*}{ Sustainable cost management information } & \multicolumn{5}{|c|}{ SMAS } & \multicolumn{5}{|c|}{ CAS } \\
\hline & 1 & 2 & 3 & 4 & 5 & 1 & 2 & 3 & 4 & 5 \\
\hline $\begin{array}{l}\text { 1- Classifying environmental costs into } \\
\text { five tires: conventional costs, hidden } \\
\text { costs, contingent costs, relationship and } \\
\text { image costs, and societal cost. } \\
\text { 2- Determining the future drivers of } \\
\text { growing risk for new environmental } \\
\text { costs: regulatory risk, supply chain risk, } \\
\text { product and technology risk, litigation } \\
\text { risk, reputation risk, and physical risk. } \\
\text { 3- Measuring environmental opportunity } \\
\text { costs: the cost related to the best- } \\
\text { unrealized pollution alternative. } \\
\text { 4- Tracing direct and indirect } \\
\text { environmental costs to products, and } \\
\text { covering the costs of waste management, } \\
\text { permits and fees, and recycling activities. } \\
\text { 5- Reviewing the profitability of polluting } \\
\text { products, and review the activities of the } \\
\text { firm to prevent these costs. } \\
\text { 6- Determining the relative resource } \\
\text { intensity of the products and processes. } \\
\text { 7- Examining the resource intensity for } \\
\text { indirect physical environmental costs for } \\
\text { products. } \\
\text { 8- The tight link between materials flow } \\
\text { information and cost information to } \\
\text { manage environmental performance cost- } \\
\text { effectively. } \\
\text { 9- Tracing the details of materials flow } \\
\text { through all the different organizational }\end{array}$ & & & & & & & & & & \\
\hline
\end{tabular}




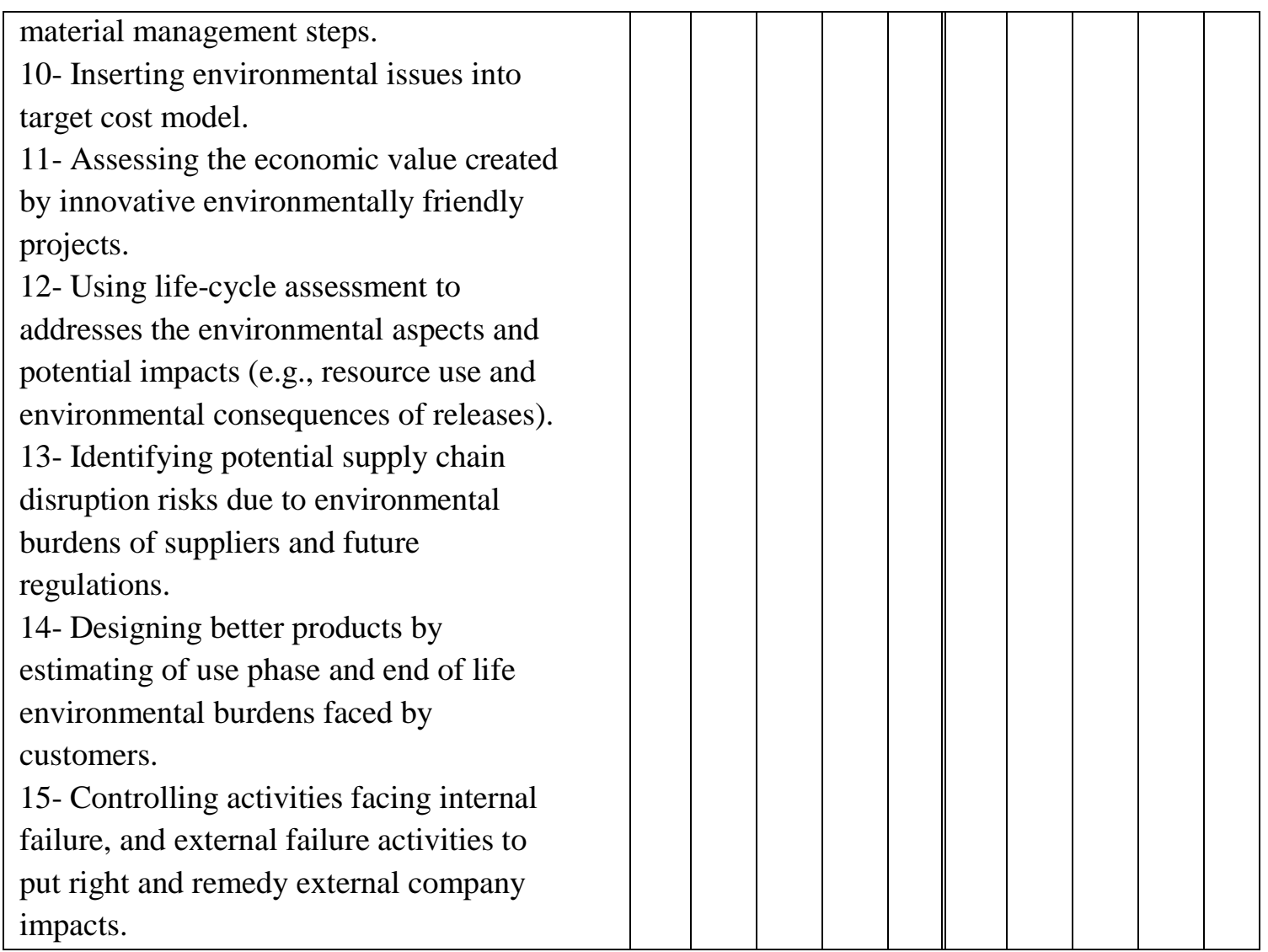




\section{Part D}

Which of the following four items should be the objectives for both SMAS and CAS?. Give your opinion:

(1) Strongly disagree;

(2) Disagree;

(3) Biased;

(4) Agree;

(5) Strongly agree.

\begin{tabular}{|l|l|l|l|l|l|l|l|l|l|l|}
\hline \multicolumn{1}{|c|}{ Objectives } & \multicolumn{3}{c||}{ SMAS } & \multicolumn{3}{c|}{ CAS } \\
\cline { 2 - 8 } & $\mathbf{1}$ & $\mathbf{2}$ & $\mathbf{3}$ & $\mathbf{4}$ & $\mathbf{5}$ & $\mathbf{1}$ & $\mathbf{2}$ & $\mathbf{3}$ & $\mathbf{4}$ & $\mathbf{5}$ \\
\hline 1- Structure the relationship between & & & & & & & & & & \\
non-monetary social and & & & & & & & & & \\
environmental activities on the one & & & & & & & & & & \\
hand, and economic success on the & & & & & & & & & & \\
other. & & & & & & & & & & \\
2- Assess appropriately the economic \\
value created by innovative \\
sustainable projects. \\
3- Accounting of the flow of physical \\
materials, wastes, and energy both \\
within and outside the organizational \\
boundaries.
\end{tabular}

